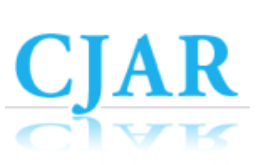

Canadian Journal of Action Research

Volume 21, Issue 3, 2021, pages 32-51

\title{
WALKING TOGETHER: ARTISTIC COLLABORATION ACROSS CULTURES IN AUSTRALIA AND NEW ZEALAND
}

\author{
Tracey M. Benson \\ University of Canberra
}

\begin{abstract}
As an artist and writer who often works across disciplines and cultures, my education into effective and respectful engagement has been built on my experience working with First Nations friends, collaborators, and Elders. The aim of this paper is to explore teachings from a number of these leading thinkers, writers, and Elders on the topic of knowledge sharing, cross-cultural awareness, and ethical engagement through practice-led research. Drawing from personal experience, it will incorporate learnings that have informed a world view that has been evolving since childhood. The paper highlights the importance of giving rightful recognition to knowledge keepers and provides some guidance for readers interested in developing productive and respectful partnerships with First Nations collaborators. Here knowledge can be safely shared and celebrated as ways to understand the world around us that are restorative and regenerative. I speak as a woman of mixed European background raised in Australia on Gubbi Gubbi Country of South East Queensland, and Larrakia Country of Darwin. Culturally, I am descended from Norse, Celt, Saxon, and Druid ancestors. Through this lived experience I hope to share learnings that support the goals of reconciliation, truth telling, and First Nations determination in my home country, as well as facilitating greater awareness for people seeking to respectfully engage with Indigenous knowledge.
\end{abstract}

KeY WoRDS: Art-Sci; Collaboration; Cultural knowledge; First Nations; Indigenous knowledge; Knowledge sharing; Media art

\section{ConteXT}

The paper is written from personal experience as a collaborator, mentee, and ally; sharing over forty years of experience living and working with First Nations peoples. This investigation of a personal life journey of learning engages the concepts that are inherent in Judi Marshall's 1999 paper titled Living Life as Inquiry (Marshall 1999). The approach gives "substance to the idea of research as a personal and political matter - and suggests that the work of an Action Researcher includes connecting and exploring the very distinctions that might, traditionally, separate the two realms" (Gearty \& Marshall 2020, para. 1). 
This paper is written with some hesitation. Although I speak from personal experience, I do not speak in any way for the cultural knowledge in the stories that are shared. The intention is not to assume Indigenous knowledge, but by way of the collaborative process, share some insights into how to respectfully and ethically engage with First Nations peoples and cultures. In this context, the essay could be described as a study in Action Research via an autoethnographic process. By using personal experiences as the frame of inquiry to explore themes related to Indigenous knowledge and collaboration as Action Research, I will explore how these engagements have influenced and changed my creative approach and process. In this way, the essay employs Connelly and Clandinin's (2006) definition of autoethnography in which personal narrative "is a portal through which a person enters the world and by which their experience of the world is interpreted and made personally meaningful" (p. 376).

In terms of applying an ethical approach to the topic, the National Health and Medical Research Council's (NHMRC) Keeping research on track II (2018) guide is used to contextualise the approach in this writing. This text is specific to Aboriginal and Torres Strait Islander peoples of Australia and is not focused on Aotearoa New Zealand or Canadian First Nations. However, the six core values of spirit and integrity, cultural continuity, equity, reciprocity, respect, and responsibility (NHMRC, 2018) have context across cultures with a robustness that can be more broadly applied. For Aotearoa New Zealand ethical protocols Te Ara Tika (2010) is used as it is an established text for researchers working with Māori people. A relative Canadian example which focuses specifically on health research involving First Nations, Inuit, and Metis people in Canada is governed by the provisions outlined in Chapter 9 of the Tri-Council Policy Statement: Ethical Conduct for Research Involving Humans (TCPS) (Canadian Institute of Health Research, 2013). Castellano (2008) reflects on the words of Elder George Courchene of Sagkeeng First Nation in Manitoba, speaking at a public hearing of the Royal Commission on Aboriginal Peoples in 1992. Elder Courchene spoke of the concept of "Indian law" which was given to the people by the Creator at the beginning of time: "He gave them four directions. He gave them sweetgrass, the tree, the animal and the rock. The sweetgrass represents kindness; the tree represents honesty; the animal, sharing; and the rock is strength" (Castellano, 2008, para. 1).

Some terms are often shifting in this paper - broadly applying "First Nations" for communities, then using the specific nation names where possible. The use of the term "Indigenous knowledge" refers to the concepts described therein.

By sharing stories from a personal perspective, the goal is to speak from a position of respect and with an appreciation of how cultural experiences operate in relation to the sharing of knowledge across disciplines and cultures. These lived and told stories and the talk about the stories are one of the ways that we fill our world with meaning and enlist one another's assistance in building lives and communities (Freeman, 2020). What feels new is the emergence of narrative methodologies in the field of social science research (Clandinin \& Rosiek, 2007, p. 35). This perspective is echoed in Judi Marshall's statement:

By living life as inquiry I mean a range of beliefs, strategies and ways of behaving which encourage me to treat little as fixed, finished, clear-cut. Rather I have an image of living continually in process, adjusting, seeing what emerges, bringing things into question. (Marshall, 1999, p. 2) 
By bringing the story of self to the relationships and collaborations which have evolved with First Nations peoples, I seek to highlight a set of values which are applied more broadly in the context of professional life as an artist and founder of social enterprise, Treecreate.org.

\section{BACKGROUND: A STORY OF LIFE LEARNING}

When I was 12 years old and living in Darwin, Australia's northernmost city and the traditional home of the Larrakia people, I went to a coeducational Catholic high school - St John's College. At this school, there were many students from all over the world as Darwin and the Northern Territory are very culturally diverse. In addition to this, there was a significant cohort of students who boarded at the school during the semester, coming from many of the Catholic mission towns around the Northern Territory. Being raised as an Anglican and going to a Catholic school was in itself a learning journey, not so much because of the religious differences in worship, but because of the many similarities of religious practice.

As a very curious child I was intrigued by the other religions of students at the school. There is a clear memory of asking a friend from the Tiwi Islands if she had her own religion, one for her people. Her response was profound and has stayed with me. My friend responded that yes, her spirituality was connected to the earth, to the stars, to dance, to art, to her family, and to her body; that spirituality was connected to everything and that in fact everything was connected it was all one and the same. Since then, this same story has been repeated countless times from friends and colleagues from First Nations cultures around the world, including Australian First Nations, Māori, Inuit, and Saami. The other important thing my friend shared was that "the land does not belong to us. We belong to the land."

In 1981, our school was very fortunate to have Miriam-Rose Ungunmerr as our art teacher. Dr Miriam-Rose Ungunmerr (AO) is an Aboriginal Elder from Nauiyu (Daly River), where she served for many years as the principal of the local Catholic primary school. She is a renowned artist, activist, writer, and public speaker (Miriam-Rose Foundation), and she was also named the 2021 Senior Australian of the Year (Australian Government, 2021). When Miriam-Rose first taught in high school, she was not long out of teachers' college and has since then gone on to be a prominent Elder and spokesperson. Most importantly, her work on creating awareness of dadirri has been far reaching. Reflecting on the concept of dadirri, Miriam-Rose states:

What I want to talk about is another special quality of my people. I believe it is the most important. It is our most unique gift. It is perhaps the greatest gift we can give to our fellow Australians. In our language, this quality is called dadirri. It is inner, deep listening and quiet, still awareness ... 'Dadirri' recognizes the deep spring that is inside us. We call on it and it calls to us. This is the gift that Australia is thirsting for. It is something like what you call "contemplation" [...] When I experience 'dadirri', I am made whole again. I can sit on the riverbank or walk through the trees; even if someone close to me has passed away, I can find my peace in this silent awareness. There is no need for words. A big part of 'dadirri' is listening. (Ungunmerr, 1988, para. 5-7)

In writing this paper, I rely heavily on storytelling related to direct experience, especially regarding my friendships and collaborations. Marshall (1999) also recognises the relationship between the personal and the professional, noting that these worlds are not, and cannot exist in isolation. She states that: 
Living life as inquiry means that I hold open the boundary between research and my life generally. Often, therefore, I am aware that a theme I am pursuing in research is also relevant to some other area of my life, and I will seek to work with, rather than suppress, that realisation. (Marshall, 1999, p. 4)

In terms of a personal context, I see this research of self, and story of self, as a form of autoethnography. John Freeman's (2020) article focused on autoethnography and Action Research suggests the process is an attempt to "exercise self-doubts through what amounts to a form of critical catharsis; a process of reflection that allows me to put my own experiences within a frame that might strike a chord with other people, turning anxiety over purpose into something constructive" (p. 86). I find his approach useful as a means to speak about my experience and learning from First Nations people. This experience has primarily taken the form of ongoing collaborations with a number of First Nations artists, researchers, and Elders in Australia and Aotearoa. These collaborations have evolved over time through a process of mutual learning, sharing, making, and reflecting, and they demonstrate how Action Research methods are very complementary in this creative context.

Although the projects discussed in this article do not address a formal engagement with Action Research as a tool, the stories focus on key collaborative and cross disciplinary research resulting in public art projects, academic papers, and presentations. By sharing these experiences, I attempt to explore ways to ethically and respectfully engage with First Nations peoples and Indigenous knowledge without impinging on moral rights and cultural intellectual property (IP). Action research in this context is seen as a means to explore processes of knowledge exchange, cultural awareness, collaboration, and co-creation.

The definition of Action Research centres on the concept of iteration, of mutual learning through connection to place and context. In the examples provided, the collaborative process is explored as a way to work together on projects which cross cultures and geographies to explore complex narratives of place, story, ecosystems, and materiality. These explorations are focused on a desire for mutual learning and co-creating knowledge. Kurt Lewin (1946) described Action Research as "a comparative research on the conditions and effects of various forms of social action and research leading to social action" that uses "a spiral of steps, each of which is composed of a circle of planning, action and fact-finding about the result of the action" (p. 201). The Action Research method primarily serves two purposes - to bring about positive change and to generate knowledge.

\section{From WHERE I SPEAK}

When considering a personal and subjective role as artist and Action Researcher in the context of collaboration with First Nations, there is a need to clearly communicate from where I speak. The iterative nature of the Action Research has formed itself through these collaborations through time. In the case of my ongoing work with Lee Joachim as an example, the collaborative process has not resulted in a single work. We have presented our earlier projects in multiple contexts, and the work evolves over time. Other pieces have also been developed collaboratively with other artists as well as part of the same ongoing dialogue. Over time, our relationship continues to evolve, and as such, the dialogue is connected with other facets of our lives through which we continue to learn from each other. 
Deborah Reed-Danahay (1997) asks whether the auto-ethnographer is an insider or an outsider of the phenomenon being described. She asks whose voice is being heard: who is speaking? The people under investigation or the researcher? The fact that these are good questions does not make them necessarily any easier to answer. In my personal case, am I an outsider? (Freeman 2020). In terms of cultural knowledge, it is clear that I am the outsider. There is no ambiguity, unlike Freeman. However, as a creative collaborator, I am definitely an insider regarding the creative process and production. This does align with identifying my perspective in this writing as an exploration into autoethnography as a process of reflection and self-critique. The intention behind autoethnography is that narratives are constructed through the interaction between people and the place in which they live (Silverman, 2000).

A number of collaborative projects have evolved from an ongoing association with the Intercreate Trust based in Aotearoa New Zealand. Intercreate is a project based organisation and has run numerous cross disciplinary residencies and public events since 2006. I attended my first SCANZ residency in 2013 and later that year joined the Intercreate Trust as a Trustee.

It needs to be stated that although the paper focuses specifically on personal experiences as a process of autoethnography, it has been reviewed by some key collaborators to ensure that this topic has been approached in a culturally respectful manner. This is Action Research in flight, in that the work continues to be informed through this process of sharing knowledge and evolving ideas in an open and evolving way. One of my collaborators commented after reading the initial draft that one of the reasons she loves to collaborate is because "you take me on the journey with you." So as I write about Action Research, I seek to enact its methods in practice, through a form of autoethnography.

John Freeman uses a similar approach in his work, asking the question: "Would the article carry more weight, or carry it differently if their words were included here, as they would be and as they will be if I choose to write about that work, rather than writing here about writing about it?" (Freeman, 2020, p. 99).

\section{SCANZ 2013: Te Aroha - Learning Te Reo Mãori Waiata in the BuS to Parihaka}

As mentioned earlier, in 2013, I participated in SCANZ 3rd Nature, organised by international arts/science/tech organisation Intercreate. I learnt about the program at the International Symposium of Electronic Arts (ISEA) in Istanbul in 2011, through another artist, Sonja Van Kerkoff, who had attended my talk about remote tech innovation and the digital divide. There were no expectations of what would unfold during the two week residency, and I could not have imagined the profound impact it would have on my emerging understanding of ethical crosscultural collaboration. In many ways it was a journey of healing, of experiencing a greater sensitivity of how to 'walk the land' as well as finding a sense of belonging. Feelings of unbelonging had weighed heavily upon my psyche, knowing the history of the lands on which I was born and my own cultural / racial identity as a fifth generation migrant from the European lands.

The first day of the residency, the group were told that we would be going to Parihaka, a community about an hour away from New Plymouth. As everyone loaded into the minibus, a couple of the Māori artists, Jo Tito and Terri Ripeka Crawford, informed us that we were going to learn a waiata (a song) to sing at the hui (meeting) we were going to. I felt challenged by this as despite having lectured and given presentations over many years, I remained quite shy and 
nervous about speaking in front of people. The artists sang the waiata for us and I was moved by the beauty and clarity of their voices. The lyrics for Te Aroha are as follows:

\author{
Te aroha \\ (Love) \\ Te whakapono \\ (Faith) \\ Me te rangimarie \\ (And peace) \\ Tatou tatou e \\ (Be amongst us all)
}

The above waiata, Te Ahora, was written by Morvin Simon in the early 1980s and comes from Whanganui (Kaiwhaiki), but is familiar to the Taranaki region where Parihaka is located (S. Lowe, personal communication, October 28, 2020).

By the time we arrived at Parihaka I was feeling very nervous, having never been on a Marae before, and knew very little of Māori customs and protocols. When the group arrived at the Marae we were asked to form a group outside the Wharenui (meeting house), with the men flanking the group of women on each side. As we waited, we heard a woman's voice call out to us in song. After calling to our group, one of the Kuia (female elders) from our group called back in response. After some to-ing and fro-ing of calls from the women, we slowly approached. Everyone removed their shoes as we entered the Wharenui. There were many iwi from Parihaka lined up around the room. As the visitors came into the house each person slowly hongi-ed with each person in greeting, noses and foreheads lightly touching, breathing in deeply. Some people shook hands, others greeting us in the Māori language, Te Reo Māori with "kia ora" or "tēnā koe." This ceremony is called the pōwhiri (or pōhiri) and is a process whereby the host people welcome visitors on the marae (Keane 2013). The call between the women mentioned earlier is known as the karanga and is a form of female oratory in which women bring a range of imagery and cultural expression to the first calls of welcome (and response) in the pōwhiri (Te Taura Whiri i te Reo Māori).

It is normal for both kaikaranga (women who carry out the karanga) to address and greet each other and the people they are representing, to address and pay tribute to the dead of each other's acquaintance (especially those who have recently died), and to refer to the reason the groups have been together (Te Taura Whiri i te Reo Māori).

Over the two weeks, a range of workshops covering culture, activism, and technology were offered as part of the residency program (Intercreate, 2013). One workshop themed "Mātauranga Māori (traditional knowledge)", led by one of the Kaumātua (Elders) Te Huirangi Waikerepuru and Te Matahiapo, continues to resonate in terms of a holistic understanding of the relationships between place, people, and identity. Te Huirangi Waikerepuru spoke about Māori cosmologies, the interconnected nature of all things, and our part within that ecosystem. His words started a journey of exploring my own ancestry and ancestral places, which took me to Norway as well as opening me up to learning more about my own genealogy through researching my family history. In introducing key concepts in regard to the ongoing states of the nature of reality - Te Huirangi spoke of the phases of Te Kore, Te Po, through to Te Ao Marama. He explained the first state of Te Kore as the void, or the space of potentiality. This 
concept explores the infinite potential that the universe offers us if we open ourselves to possibility.

At the time, I wrote quite a few blogs on the topic, respectfully asking one of the Trustees, Parihaka descendant, Jo Tito, to review my writing to make sure it was appropriate. This excerpt talks about the importance of understanding whakapapa:

One of the things that has really been powerful for me is how Māori people identify people they meet. When you meet Māori the way you introduce yourself is through where you come from (where you were born) and your ancestors. This is very different to a European or 'western' way of knowing a person, say through their qualifications, work and academic achievements. For me, the connection to place as informing identity and 'meeting' each other, offers a rich possibility for linking and sharing experiences. (Benson, 2013b, para. 2)

At the beginning of this paper, I introduced myself in respect to my ancestral ties in Europe. Although my ancestors have lived in these lands called Australia for five generations, it is only a moment in comparison to the connections to the Ngunnawal lands on which I live, and indeed the connection that First Nations people have to their Country. When asking an Elder in Aotearoa, New Zealand how to connect with the land and find the pathway to healing between worlds, he responded by saying that we need to "find out about our own lands, our own ancestors." Tyson Yunkaporta also recently commented that it was "not that long ago when you Europeans were hunting bison" (Schrei, 2020, 9:15). The Norse, Celts, and Druids all celebrated the change of the seasons and honoured nature, and while the ceremonies, rituals, and deities were different, there were stories which informed an understanding of the world and the universe around us.

Kuku-Yalanji educator and communicator Luke Briscoe reiterates the need for scientists and others to look to their own ancestral roots to find approaches that have a similar spiritual and ecological underpinning to Australian Indigenous knowledge (Aliento 2018). Briscoe's (2016) article, How we can help White Australia connect with an Indigenous Mind, offers a pathway not only for respectful dialogue, it offers a pathway for reconnection and reconciliation, "If White Australia find an Indigenous mind from their own ancient perspectives, I believe this will build better relationships and respect toward each other and create a value system that will restore our political and social landscape" (Briscoe 2016).

These kinds of gestures from First Nations peoples are incredibly generous. Even after all that has happened in these colonised lands, there is the potential for all people to connect to Indigenous knowledge. Briscoe also comments, "My first thought on this notion was that White Society doesn't deserve to reconnect with its Indigenous self. I mean after all, they have afflicted so much hate towards Indigenous people through colonisation, and by doing so, they have created a social discourse; the destruction and isolation from the natural world and infected us with these values" (Briscoe, 2016, para. 2). But he does not sit with these thoughts, offering many practical ways for the broader community to build stronger connections and awareness of Indigenous knowledge. Time and time again, I have witnessed this generosity of spirit and leadership from First Nations peoples. 
What is also critical is to ensure that research is managed in ethical and respectful ways, with full support from First Nations participants and communities. In seeking to understand Action Research from a similar colonial context, Brian Beaton and Penny Carpenter focus on creating meaningful working relationships with First Nations communities in remote Canada in their article Creating appropriate participatory action research with remote First Nations. In the introduction they recognise and honour "the unceded traditional territories of the Wolastoqey nation as the place for the creation of this article is an essential step for the authors" (Beaton, 2015 , p. 50). This is a very similar practice to what is becoming more commonplace in Australia, where traditional custodians (First Nations) are acknowledged and respects are paid to Elders. Although this might appear as a small gesture, it clearly positions the importance of connection to place for First Nations peoples and the complexity of living on colonised lands. It is an act which also supports self-determination and recognition of culture through acknowledgement and respect. This is critical to working collaboratively with First Nations. As Beaton comments, "First Nations are addressing contemporary challenges in many ways and researchers working with them must use appropriate and respectful research methodologies" (Beaton, 2015, p. 56).

This complicated relationship with land, history, and story is vexing not only for sovereign peoples. There is also uncertainty about how to effectively and meaningfully engage with communities if you are from a non-Indigenous cultural background. For many, myself included, there is a sense of belonging and unbelonging when the realms of the ancestors are distanced through geography and time.

\section{BELONGING / UNBELONGING}

This notion of belonging and unbelonging has shaped not only my creative practice, but my own sense of identity and cultural awareness. As a fifth generation migrant, my links to my ancestors are fractured and lost in the waves. To add to this, I live in a land that was stolen, for which there is no treaty and no clear way forward (Benson, 2019). Much of my emerging work as an artist grappled with a personal sense of place, identity, and belonging. For example, in an earlier project Big Banana Time Inc. (1995-2001), these concerns were expressed through a playful critique of tourism and consumer culture, in particular the motif of the souvenir.

More recently, the notion of belonging and unbelonging was further explored through the studio element of my PhD project, drawing some of the ideas expressed in Marc Augé's Non Places (1995). Although the non-places were about in-between places of transit, they were identified as relative - as the notion of home was not one that necessarily came with a sense of comfort and contentment. In this context, Connelly and Clandinin's (2006) definition of place is problematic in regards to the telling of history (or untelling). They define place as "the specific concrete, physical and topological boundaries of place or sequences of places where the inquiry and events take place" (p. 480). The key to this commonplace is recognizing that "all events take place some place" (p. 481). The land, however, reveals the stories which were not written into the colonial telling of history. Once there is awareness of the continuing cultural connections to these lands, it is impossible not to recognise the remnants of past human activity.

When I walk on the ancient lands of my birth I see the shape of the land and its materiality, reminding me of this deep past. These places are everywhere in Australia, if you open your eyes. Fish traps along the coasts and our rivers, midden heaps - a legacy of coastal living and bounty, the tracks of the land. One of the most 
powerful reminders is our highway system - song lines, trade routes and walking tracks. (Benson, 2019, p. 388).

\section{Collaboration Across Cultures: Practice-Led Action Research}

Science and the Humanities are increasingly acknowledging the importance of collaborative approaches to the production of place-based knowledge, which include First Nations and local knowledge. For example, in a number of Australian universities there have been positive efforts to align this knowledge alongside western knowledge systems. The University of Canberra, and especially it's Centre for Applied Water Science, works closely with knowledge keepers to build a holistic perspective on understanding environments and cultural practices that focus on Caring for Country. Wheeler and Bernstein (2020) state:

Links between knowledge and information, and management and decisions are often complex with diffuse, multiscale relationships between information and knowledge and decision-making. These processes involving [sic] many political actors and interest groups which may be either integrated in or separate from knowledge production and synthesis. (p. 1638)

They go on to write, "Indigenous and local knowledges comprise a diverse set of understandings and practices, and therefore approaches must reflect those understandings and the local contexts in which they are placed" (Wheeler \& Bernstein, 2020, p. 1640). They also acknowledge the complexity in ensuring that divergent knowledge systems have an equitable voice. "The challenge when working with multiple knowledge systems to inform decisionmaking is what approach will best allow these knowledge systems to be evaluated fairly and used appropriately" (Wheeler \& Bernstein, 2020, p. 1641).

The relational aspects of bringing together the complexity of a diversity of knowledge, experience, and culture to bear on creative collaboration is benefited by adopting Action Research methods, even informally. Over time trust is built, as well as understanding about how people work together and learn from each other. Also having time to reflect and debrief is core to identify the next steps of co-creation. In the following sections, a number of projects with First Nations collaborators are discussed with the common denominator being that these collaborations continue over time, with the ideas being refined and shaped through iterations.

\section{WAY OF THE Turtle: EXCHANGING BREATH}

Since 2014, The Way of the Turtle has been a vehicle for Yorta Yorta researcher Lee Joachim and myself to collaborate across cultures and geographies. In 2016, we participated in Water, Peace, Power, a residency and exhibition program co-organised between Intercreate and Parihaka Kuia, Maata Wharehoka. Lee and I collaborated with a range of contributors to create a work exploring the cross-cultural relationships between place and story. The work was created with Yorta Yorta Country turtle nesting data shared from TurtleSat, tech support from Martin Drury, Andrew Hornblow and Nigel Helyer, together with contributions of song and story from Parihaka descendent Jo Tito and Yorta Yorta Elder and language expert Sharon Atkinson. We used the motif of the spiral to connect ideas of time, place, and culture. This light and sound work was presented in situ at Parihaka in the grounds, installed on a rock wall under the shade of some large trees (See https://vimeo.com/158796370 for documentation). Although the work on a visual level was subtle and somewhat tucked away, people were drawn to the song and story in the audio and the subtle patterning of the lights which pulsed the 
patterns of the nesting data. Lee and I later presented this work as a paper at the Land Dialogues conference in Wagga Wagga. We highlighted the critical role of collaboration as a means of approaching social and environmental justice, stating: "The Way of the Turtle project is grounded in the goal of social justice and empowerment through the learning and sharing of knowledge through active collaboration (Benson \& Joachim, 2016, p. 164). Through a process of sharing across cultures, and knowledges, the Way of the Turtle project remains active, through continuing conversations between Lee Joachim and myself.

\section{SCANZ 2017: Magic of Te Māhia}

When Miriam-Rose talks about dadirri, she is clear that it is something that everyone has the potential to access as it is a way of experience that everyone needs - a sense of reconnection and belonging through deep listening. Her words reinforce the importance of finding connection, with each other, the river, the trees, the silence and all living beings. Anita Heiss also writes of the need to focus on what brings us together - the points of similarity rather than difference:

It's about being human beings. When we think about it, we've got more in common than we haven't. Rather than look at each other and think what makes us different, let's think about what we have in common. (Hardy, 2014, para. 7)

This sentiment echoed through my experience at SCANZ 2017 based at Taipōrutu, Te Māhiamai-Tawhiti on the ancestral lands of one of the co-organisers, Desna Whaanga-Schollum. This artist residency co-organised between Desna and Intercreate Trustee Jo Tito explored a playful emphasis on creative process over production. Over the ten days, many rich conversations were shared along with plenty of good kai (food). At the time, I was focusing deeply on the iconography and language of the Runes, in particular the Elder Futhark, the oldest runic alphabet. This sparked the interest of a number of the other artists including Terangi Roimata Kutia-Tatuarangi, sharing many conversations about the similarity of motifs between Norse and Māori cultures. This resulted in us co-creating some runes, which we released at Te Whanga $\bar{a}$ Ruawharo beach, recording the event. It was in many ways a performance, with a waiata sung by Terangi as we let the ocean capture the decorated stones and carry them to sea.

At the same residency, another collaboration between a Māori and an Inuit artist from the northern territories of Canada was emerging in terms of relational modes of connection, through song, throat singing, weaving, and traditional tattoo practices. This collaboration has also been evolving over a number of years through the same residencies in New Zealand. The continuing relationships through this creative and culturally diverse network have resulted in numerous ongoing collaborations all over the world.

\section{Collaborations with Maata Wharehoka: Puanga - The Sound of Silence}

In 2019, I again went to Parihaka, this time to work closely with Maata Wharehoka, a dear friend and Kuia. We had spoken on and off since 2015 about the potential of collaborating on a project. Our project would tie to Puanga, and the Puanga festival at Parihaka.

Puanga is the star Rigel and is the brightest star in the Orion constellation. Matariki is seen below Puanga and to the left of Tautoru (the three stars of Orion's Belt) in the late autumn and early winter night sky. (Te Papa, n.d., para. 7) 
In Taranaki, the Māori new year is acknowledged with the rise of Puanga, whereas on the east coast Matariki is celebrated. This is because "Puanga is given prominence mainly because some iwi struggle to see Matariki clearly from their locality and therefore look to the next important star near Matariki. That star is Puanga" (Te Papa, n.d., para. 4).

Our project would bring together our cultural perspectives through a range of media, handmade books, and weaving. Maata's books focused on Puanga and Māori cosmologies, whereas my books explored Norse cosmologies tied to the Poetic Edda (n.d.), Runes and the world tree Yggdrasil.

Here is a poem Maata wrote about Puanga which was published online at the time:

The Silence: Puanga

We cannot hear the voice of Puanga

We can only gaze upon its radiance

Its beauty in the arms of Ranginui

In the Western sky

Aotearoa

Puanga remains silent

Competing with other stars

To shine

To shine so brightly

To be seen beyond the cosmic realm

Mysteriously it gazes upon human forms

Reminding them to make ready

Clear the land

Check its yield

Return the spirit of the ancestors

Rest

Huddle down for the winter

Prepare babies for Papatuanuku

There will be food aplenty

Growth

New Moon - Early June

Full Moon - End of June

A reminder

All that is in the realm of earth and sky

Belong to the Atua

\section{Maata Wharehoka 2019}

Since we worked together on that project, we have reflected on our collaboration and have continued to evolve our ways of bringing together ideas. For example, in 2021, I returned for the Puanga festival and we worked with another artist to create an Atua with Harakeke in a workshop with other weavers of all levels of experience. We also recorded more video and audio to co-create a record of our ongoing work. Although informal in approach, we have used Action Research as a way of planning, learning, doing, and reflecting on the process of our collaboration to continue to develop our work together. 
Benson

\section{Bridging Pathways}

Internationally and even within Australia, there is not a standard in how we speak about First Nations cultures and Indigenous knowledge. Now those specificities, if determined by the said community, should be respected. There are some clear protocols in the Australian context. For example, capitalising words - Aboriginal, not aboriginal; Indigenous, not indigenous (Oxfam 2015). It is also important in Australia to use the specific name of the cultural group / country where possible.

One of the significant transformations has been in the context of public sector innovation to include a more holistic approach to policy design. This has been a difficult space for policy as it shifts from an objective rationalised perspective to a contextual and relational perspective where the person as a whole being is considered. McKenzie et al. (2017) comment that "in our professional lives and workplaces, talking about 'heart' is enough to make anyone cringe. But working with systems is about working with people. And as humans, we respond to things that trigger our emotions, our creativity and our curiosity. We seek connection and meaning" (p. 13). This statement ties back to the concept of dadirri and deep listening as a means to get to the heart of the matter. It is a way of listening with the whole body as part of a connected system which seeks understanding.

Also, every culture has its own set of customs and protocols. Because of the ongoing relationship with Aotearoa New Zealand and Intercreate, I have more familiarity with Māori protocols and language. Over the years, I have picked up some Te Reo Māori, which is a beautiful evocative language. From that first attempt on the bus all those years ago to sing a single waitata, I have moved towards an understanding of some common day words and expressions. This is Action Research as lived experience. I wish I could say the same for my knowledge of the cultures of the places where I have lived in Australia. As a child in Darwin, we picked up a lot of Aboriginal English not realising at the time the history of words like 'budoo' and 'bunji'. Darwin kids all spoke these words and other appropriated English words like 'gammon' and 'deadly'. Children have a great ability to just exist within the cultures they find themselves in.

These days I do not use these words in my everyday speech often, but when I find myself in the company of old friends from the north, my vernacular slips back to these long loved familiar words. I am also much more aware of the importance of cultural respect and the impact of cultural appropriation on First Nation peoples. A useful definition of my understanding of cultural appropriation, and one that Bruce Ziff posits, is "the taking - from a culture that is not one's own - of intellectual property, cultural expressions or artefacts, history and ways of knowledge" (Ziff \& Rao, 1997, p. 48).

There are also many formal cultural protocols which should be followed to show respect in an Australian context. The Oxfam Australia (2015) guide is an excellent example of how an organisation has included cultural protocols into its operation. For example, a Welcome to Country from a local Elder and Acknowledgement of Country are now standard protocol at events. There are some good examples of how Indigenous knowledge has made itself into the mainstream of policy and public sector delivery. The Wayfinders Guide to Systems Transformation (McKenzie et al., 2017) uses the Mau Piailug star compass to consider a holistic approach to systems change:

With great respect, we have used the analogy of Polynesian wayfinding. Traditional Polynesian navigation has been used for thousands of years to make long voyages

The Canadian Journal of Action Research, Volume 21, Issue 3 (2021), 32-51 
across thousands of miles of the open Pacific Ocean. Involving navigational instruments such the Mau Piailug star compass, wayfinders also rely on the careful observation of waves and currents. They embody a powerful combination of vision, deep understanding of the natural world, and a lifetime of learning and practice. ( $p$. 3)

The reference to a deep understanding of the natural world evokes the concept of dadirri, through a process of paying close attention and listening to the more-than-human voices that we coexist with. Interestingly the Guide goes on to state:

Spaces for collaboration are always potential spaces for contest. Use it as a creative driver. Likewise, there will be those that have been silenced so long they struggle to find a voice." This has never been my experience of the collaborative process. Perhaps because within the workings of the collaborations I have experienced there has been a willingness to actively listen and to focus on the commonalities, rather than the egoistic need to assert control. (p. 7)

Freeman posits how autoethnography in his case was not about a predominance of his voice in a shared story, but how only he can ask the questions, which resulted in the exploration of collaboration process:

Were this article the end-result of a fully formed Action Research project then the predominance of my voice might be troublesome, but this article is not that. This writing is not so much an attempt at imbuing a process with validity in the eyes of my academic colleagues so much as a questioning of where validity and value lie and the extent to which we might shape what we do into what we want. In a context such as that, whose voice can I ask that question with but my own? (Freeman, 2020, p. 100)

His approach resonates with my own attempt to give context to my experience working with First Nations communities and collaborators. As I write this, I am far from the many places I write of, and yet these experiences shape my everyday experience with the world. Although I am far from the tropical coast of my youth or the soft whenua (lands) of Aotearoa New Zealand, I have learned to see the Ngunnawal lands on which I live for their own beauty and power. Nestled in the valley of the Brindabella Mountains, we walk along the Ginninderry creek and sit near the ancient axe grinding grooves to listen to the birdsong.

\section{Conclusion}

Without a doubt, in Australia and in many colonised lands, there are sacred places everywhere tucked alongside in the modernity of the suburbs. These places are also available in countries not readily associated with a history of colonisation. I find it intriguing that in Europe in particular, people do not readily see how their lands bear the history of multiple acts of colonisation and occupation. Look closer. It is in your DNA. My Yorkshire ancestors have blood lines going back to the Vikings, and before that, the Celts. England is a rich study on heterogeneous and multiple cultural exchanges and stories. The stone circles bear the reminders, as do some of the rituals and customs still observed throughout the year. We just need to pay closer attention, to listen deeply, as Miriam-Rose guides us in her reading of dadirri. 
A three month residency in Norway demonstrated this tangibility of story, place, and layers of history. Wandering along the suburban streets of one of my ancestral places, Drammen, I found rock carvings of whales that are many thousands of years old. This discovery reinforces the lessons that Briscoe and Yunkaporta offer people like myself, caught in between culture, place, and history. It is this kind of knowledge which we can all tap into as part of our genealogy that also ties to an honouring of the cycles of the seasons, the movements of the stars, and the migration of the whales.

In this article, I have focused on my personal experience as a form of autoethnography and Action Research to explore the concept of engaging with Indigenous knowledge. The cyclical nature of an Indigenous worldview in context to collaborative creative practice over time demonstrates a strong alignment to Action Research methods. Through the telling of my story, living life as a form of active inquiry, through collaborations, formal teachings, friendships, and mutual learning, this narrative weaves together action, reflection, and ongoing dialogue. This perspective is intended as an honouring of Indigenous knowledge to understanding the lands, waters, and sky, as well as our place within these realms. All of us have a doorway to this knowledge through the pathways of our ancestry. Regardless of what our stories are, they can be activated through creative process and meaningful engagement. By understanding the world through relationships and constant cyclical change, there are many synergies between the construction of Indigenous knowledge and Action Research which build on the premise of shared knowledge through those cyclical understandings and iterations. In terms of the social change that is also an aspect of Action Research, it is inherent in an adoption of greater awareness of place, genealogy, and mutual respect. Using collaboration and co-creation in the context of developing art projects not only enhances these features for the artists / researchers, it also presents to the audiences of these works a way of framing knowledge that is inclusive and encourages greater awareness of how Indigenous knowledge is a living way of being in the world.

\section{ACKNOWLEDGEMENTS}

Many people need to be acknowledged in this article as it has been through friendship and collaboration that so much has grown into the world view expressed in this piece of writing. Firstly, the ongoing connection to SCANZ and the Intercreate Trust has been integral to my interdisciplinary learning. Intercreate's ongoing association with Te Matahiapo has been very important not just for Intercreate, but on a personal level, my friendship with Inahaa Te Urutahi Waikerepuru and Kura Puke and the teachings of Te Huirangi Waikerepuru (Taranaki Tūkau; Te Atiawa, Ngāti Ruanui, Ngā Rauru, Ngā Puhi). Parihaka kuia, friend and mentor Maata Wharehoka has taught me so much, not just about Tikanga Māori but also about myself, in ways I am still learning to understand at a deep and profound level. My good friends and collaborators Jo Tito, Lee Joachim, Desna Whaanga-Schollum and Josiah Jordan, I greatly value our ongoing conversations, insights, and chances for a good belly laugh. I also acknowledge the Parihaka community, where I have been treated like whānau and have learned so much with each visit. It is impossible to name the many First Nation friends and teachers who have shaped my worldview from a young age, but I do want to acknowledge Miriam-Rose Ungunmerr. Miriam-Rose on my year 10 report card gave me an " $A$ " for my creative work but commented that I was a "very naughty girl." When I reflect back, I agree that, yes, I was naughty and challenging as a teen. However, from that questioning and challenging child, evolved an adult seeking to better understand the stories of this country with respect, fully acknowledging that my migrant identity is forged by the privilege bestowed on me at birth; Privilege that is the 
result of colonial occupation and the oppression of the First Nations peoples of this land. Thank you to Martin Drury, Desna Whaanga-Schollum, Josie Auger, Lee Joachim, Inahaa Te Urutahi Waikerepuru, Maata Wharehoka, Kura Puke, and Sebastian Lowe for reviewing this article and providing feedback prior to submission.

\section{Permissions}

This article has been compiled with the permission of the following colleagues and collaborators: Jo Tito (Taranaki, Ngāti Pikiao, Tūhourangi-Ngāti Wāhiao, Te Whānau a Apanui), Terangi Roimata Kutia-Tatuarangi, Lee Joachim, Maata Wharehoka, Inahaa Te Urutahi Waikerepuru (Taranaki Tūkau, Tāngahoe, Tuhourangi, Ngāti Whakaue, Ngā Puhi), Kura Puke (Te Atiawa), Desna Whaanga-Schollum (Rongomaiwahine, Kahungunu, Pahauwera) and Josiah Jordan. Prior permission was also sought from Miriam-Rose Ungunmerr to reference Dadirri. Sharon Atkinson and Jo Tito also provided permission for Way of the Turtle to incorporate their audio recordings into the project for Water, Peace, Power 2016 at Parihaka.

\section{GLOSSARY}

$\begin{array}{ll}\text { Te Reo Mãori } & \text { English } \\ \text { Hongi } & \text { To press noses in traditional greeting } \\ \text { Iwi } & \text { Extended kinship group, tribe, nation, people, nationality, } \\ \text { race - often refers to a large group of people descended from } \\ \text { a common ancestor and associated with a distinct territory. } \\ \text { Also means strength / bone. } \\ \text { Women who carry out the karanga } \\ \text { Kaikaranga } \\ \text { Karakia } \\ \text { Karanga } & \text { An exchange of calls that takes place during the time a } \\ & \text { visiting group moves onto the marae or into the formal } \\ \text { meeting area. } & \text { Idea/theme/topic } \\ \text { Kaupapa } & \text { Elder, Leader, Spokespeople } \\ \text { Kaumātua } & \text { Basket } \\ \text { Kete } & \text { Authority of land or territory } \\ \text { Mana whenua } & \text { Indigenous person of Aotearoa New Zealand } \\ \text { Māori } & \text { A courtyard and usually a complex of buildings - created by } \\ \text { Marae } & \text { an iwi/hapu or organisation (under the care of an iwi) used } \\ \text { as gathering place for Māori to connect with their extended } \\ \text { families and tribal identity. } \\ \text { Person of non-Māori descent (usually European) } \\ \text { Tākehā }\end{array}$


Te Kore

Tikanga Māori

Waiata

Whakapapa

Whanau

Whare

Wharenui

Whenua

\section{Aboriginal Words}

Budoo

Bunji

Deadly

Gammon
A traditional pre-European concept, of which the Te Kore whakapapa or genealogy sets out a sequence that while it marks cosmological steps about the evolution of the universe, also relates to the ongoing states and developments.

Correct procedure, custom, system of values and principles to live by.

Song, chant, psalm

Genealogy and associated histories, Worldview

Family

House, residence

Literally big house; Communal house of the Māori people of New Zealand generally situated as the focal point of a marae.

Land, country, nation, state

\section{English}

Penis. For example, "Lookout doing a shakealeg with a laplap on, ya budoo might come out."

Friend, mate

Although this is not an Aboriginal word, it has taken its own meaning among Aboriginal society. Deadly to Aboriginal people means excellent/amazing/really good. This can be quite confusing to non Aboriginal people who might witness someone's artwork being described as Deadly.

Can mean fake; for example, "He's gammon, he thinks he's good but he's never played football in his life." Can mean pathetic; for example, "This didgeridoo from Indonesia is gammon, a garden hose would sound better." Or, to pretend; for example, "Just gammon mum- I wasn't really trying to sneak out."

Sources: Māori Dictionary 2020; Puke and Lowe, 2020; Te Taura Whiri i te Reo Māori (2020); Welcome to Country (2019). 
Benson

\section{REFERENCES}

Aliento, W. (2020). Look to your own ancestry to understand Indigenous approaches to sustainability, The Fifth Estate. https://www.thefifthestate.com.au/articles/ancestryindigenous-approaches-sustainability/

Augé, M. (1995). Non Places: An introduction to supermodernity. Verso

Australian Government. (2021). Dr Miriam-Rose Ungunmerr Baumann AM named 2021 Senior Australian of the Year. https://www.indigenous.gov.au/news-andmedia/stories/miriam-rose-ungunmerr-baumann-2021-senior-australian-year

Beaton, B. (2015). Creating appropriate participatory action research with remote First Nations. Antistasis, 5(2), https://journals.lib.unb.ca/index.php/antistasis/ article/view/24295

Benson, T. (2013a). SCANZ Update. https://remotexmedia.wordpress.com/2013/01/23/scanz2013update/

Benson, T. (2013b). SCANZ 2013: Crossing borders - identity, culture and place. https://mediakult.wordpress.com/2013/01/29/crossing-borders-identity-culture-and-place/

Benson, T., Joachim, L., (2016). Way of the Turtle: Towards empowering community and building culture. Fusion Journal, 10, Land Dialogues: Interdisciplinary research in dialogue with land. http://fusion-journal.com/wp-content/uploads/2016/11/08Benson-Joachim.pdf

Benson, T. (2016). Belonging and unbelonging: Place, ancestors, memory. https://traceybenson.com/2016/07/18/belonging-and-unbelonging-place-ancestorsmemory-simresidency-theclippertonproject/

Benson, T. (2019). Borderlands: Disruptions between remote map-making and local readings of place. Walking Practices, Walking Art, Walking Bodies. Prespa, Greece, June 30th to July 7th 2019 (in print).

Benson, T. and Wharehoka, M. (2019). The silence of Punage: The story of Puanga. https://traceybenson.com/2019/06/10/the-silence-puanga-the-story-of-puanga/

Briscoe, L. (2016). How we can help White Australia connect with an Indigenous mind, NITV. https://www.sbs.com.au/nitv/article/2016/07/15/how-we-can-help-white-australiaconnect-indigenous-mind

Castellano, M.B. (2008). Aboriginal Ethics Guide Ethical Research, Visions Journal, 5(1), 22-23.

Canadian Institute of Health Research. (2013). CIHR guidelines for health research involving Aboriginal people (2007-2010). https://cihr-irsc.gc.ca/e/29134.html

Clandinin, D. J., \& Rosiek, J. (2007). Mapping a landscape of narrative inquiry: Borderland spaces and tensions. In D. J. Clandinin (Ed.), Handbook of narrative inquiry: Mapping a methodology (pp 35-75). Sage. 
Connelly, F. M., \& Clandinin, D. J. (2006). 'Narrative inquiry'. In: J. L Green, G. Camilli \& P. B. Elmore (Eds.), Handbook of Complementary Methods in Education Research (pp 375385). Lawrence Erlbaum.

Freeman, J. (2020). Projects with people, participant-coercion and the autoethnographical invite. Canadian Journal of Action Research, 20(2), 85-103.

Gearty, M. R., Marshall, J. (2020). Living life as inquiry - A systemic practice for change agents. Systematic Practice and Action Research. https://doi.org/10.1007/s11213-020-095394

Hardy, K., (2014). For Anita Heiss, there's similarities in diversity. Sydney Morning Herald https://www.smh.com.au/entertainment/books/for-anita-heiss-theres-similarities-in -diversity-20140401-35vg7.html

Heiss, A. (2015). Tiddas. Simon and Schuster.

Intercreate (2013). SCANZ 2013 Events. http://www.intercreate.org/category/scanz2013/2013-events/

Keane, B. (n.d.). Marae protocol - te kawa o te marae - Pōwhiri process, Te Ara - the Encyclopedia of New Zealand. http://www.TeAra.govt.nz/en/marae-protocol-te-kawa-o-temarae/page-2

Lewin, K. (1946). Action research and minority problems. In G. W. Lewin (Ed.), Resolving Social conflict (pp 201-216). Harper \& Row.

Māori Dictionary. (2020). https://maoridictionary.co.nz/

Marshall, J. (1999). Living life as inquiry, Systemic Practice and Action Research 12(2):155-171

McKenzie, F., Beaudoin, Y., Birtles, J., Chatterton, P., Gillinson, S., Killick, S., Mannov, A., Munk, J., Roberts, A., Rose, V., Seneque, M., Siodmok, A., Trebeck, K. \& Van den Broeck, D., (2017). A wayfinder's guide to systems transformation: 18 insights for catalysts and convenors. Australian Futures Project. http://files.australianfutures.org/WAYFINDERS-GUIDE2017.pdf

Miriam Rose Foundation. (n.d). Who is Miriam-Rose? http://www.miriamrosefoun dation.org.au/about-us/who-miriamrose

National Health and Medical Research Council (NHMRC). (2018). Keeping research on track II: A companion document to ethical conduct in research with Aboriginal and Torres Strait Islander Peoples and communities: Guidelines for researchers and stakeholders. Commonwealth of Australia.

National Digital Forum. (2020). Waiata. http://www.ndf.org.nz/waiata/ 
Benson

Oxfam Australia. (2015). Aboriginal and Torres Strait Ilander cultural protocols. https://www.oxfam.org.au/wp-content/uploads/2015/11/2015-74-ATSI-CulturalProtocols-update_WEB.pdf

"The Poetic Edda." (n..d.) Trans. Henry Adams Bellows (1936). https://www.sacredtexts.com/neu/poe/index.htm

Puke, W. T. and Lowe, S. J. (2020). What does a shared space look like? A dialogue of a research partnership. Indigenous research ethics: Claiming research sovereignty beyond deficit and the colonial legacy advances in research ethics and integrity, 6, 247-260.

Reed-Danahay, D. E. (1997). Introduction. In D. E. Reed-Danahay (Ed.), Auto/ethnography: Rewriting the self and the social. 1-17. Berg.

Silverman, D. (2000). Doing qualitative research: A practical handbook. Sage.

Te Papa. (n.d). The difference between Puanga and Matariki. https://www.tepapa.govt.nz/discover-collections/read-watch-play/maori/matarikimaori-new-year/what-matariki/difference-between-matariki-puanga\#main-content

Te Taura Whiri i te Reo Māori. (2020). Māori Language Commission. https://www.tetaurawhiri.govt.nz/en/learn/tikanga/karanga/

TurtleSat. (n.d). Homepage. https://turtlesat.org.au/turtlesat/default.aspx

Schrei, J. (2020). Sand talk with Tyson Yunkaporta. The Emerald Podcast, https://open.spotify.com/episode/5rFo2hLvWHVuwTAtrKIpWM?si=IQKBrsovTeOz5x v3Pjzx8g

Ungunmerr, M.-R. (1988). Dadirri: Inner deep listening and quiet still awareness. Miriam-Rose Foundation. https://www.miriamrosefoundation.org.au/dadirri

Ungunmerr, M.-R. (1998). About Dadirri. Miriam Rose Foundation. https://www.miriamrosefoundation.org.au/about-dadirri

Waikerepuru, T. H. (2013). Conversation, SCANZ 2013 Workshop, WITT, New Plymouth.

Welcome to Country. (2019). 27 Aboriginal words and phrases that all Australians should know. https://www.welcometocountry.org/26-aboriginal-words-australians-should-know/

Wheeler, H. C., Root-Bernstein, M. (2020). Informing decision-making with Indigenous and local knowledge and science. Journal of Applied Ecology, John Wiley and Sons.

Yunkaporta, T. (2019). Sand talk: How Indigenous thinking can save the world. The Text Publishing Company.

Ziff, B., \& Rao, P. (Eds.). (1997). Borrowed power: Essays on cultural appropriation. Rutgers University Press. 
Dr. Tracey M. Benson is an Australian based interdisciplinary artist, researcher and founder of Treecreate. Her work focuses on issues related to belonging, place, wellbeing, and proenvironmental behaviour change. Walking is central to her creative practice by exploring locative and augmented media tools to engage audiences to see their local places with fresh eyes. Her work has been presented internationally in media arts festivals and exhibitions. With a passion for understanding different knowledge systems and engaging audiences, she often collaborates with Indigenous communities, historians, technologists, and scientists. She lectures internationally and holds adjunct positions at University of Canberra, the More than Human Lab at Victoria University, Wellington, NZ, the eXtended Reality Collective at Charles Sturt University, and is an Advisor for the TransArt Institute. She is listed as an expert with the Australian Academy of Science for her work on citizen engagement and behaviour change around energy and household sustainability.

Website: www.traceybenson.com 